\title{
More Inequality, Less Social Mobility ${ }^{*}$
}

\author{
Dan Andrews \\ Kennedy School of Government \\ Harvard University \\ dan_andrews@ksg07.harvard.edu
}

\author{
Andrew Leigh \\ Research School of Social Sciences \\ Australian National University \\ andrew.leigh@anu.edu.au \\ http://econrsss.anu.edu.au/ aleigh/
}

\begin{abstract}
We investigate the relationship between inequality and intergenerational mobility. Proxying fathers' earnings with using detailed occupational data, we find that sons who grew up in countries that were more unequal in the 1970s were less likely to have experienced social mobility by the late-1990s.
\end{abstract}

Keywords: intergenerational mobility, income distribution, equality of opportunity JEL Codes: D31, J62, N30

${ }^{*}$ We thank Christopher Jencks for valuable comments on an earlier draft. 


\section{Introduction}

A common view among citizens of large industrialized countries is that economic inequality is fair, provided there are equal opportunities. ${ }^{1}$ At the same time, there tends to be a belief that equal opportunity norms are violated when the degree of intergenerational mobility is low and family background exerts a strong influence on children's income in adulthood. It is therefore reasonable to think that inequality may be more acceptable in a society with a high level of social mobility.

Despite this important conceptual nexus between social mobility and inequality, the literatures on inequality and intergenerational mobility have largely developed in isolation from one another. That very little is known about the association between inequality and intergenerational mobility stands in contrast to the burgeoning literature on the consequences of inequality for variables such as economic growth, health and political behavior. To the extent that other studies have looked at the relationship between inequality and social mobility, the analysis has been descriptive, or focused around the question of 'American exceptionalism'. We know of no previous study that has formally tested the hypothesis that there is a relationship between a country's level of inequality and the degree of intergenerational mobility.

From a theoretical perspective, the relationship between inequality and intergenerational mobility is unclear. One possibility is that when inequality between parents increases,

\footnotetext{
${ }^{1}$ In 1991, almost all adults in West Germany, Britain, and the United States, and a majority of adults in Japan, agreed with the statement "It's fair if people have more money and wealth, but only if there are equal opportunities.” (Jencks \& Tach 2006).
} 
intergenerational mobility will fall because it is easier for rich parents to buy their children educational advantages that less well-off parents cannot afford (Burtless \& Jencks 2003). But as Solon (2004) argues, this effect will be undermined to the extent that children from less advantaged backgrounds disproportionately benefit from public programs.

Another channel through which inequality might affect intergenerational mobility is via the demand for redistribution. In more unequal societies, the median voter will tend to lie further below the mean income and may have a stronger preference for redistribution (Alesina \& Glaeser 2004). Conversely, if higher inequality increases the political influence of the wealthy - perhaps through campaign finance contributions - then the scope for government to institute progressive policies may narrow (Burtless \& Jencks 2003). Finally, higher inequality might reduce intergenerational mobility to the extent that it leads to segregation along income lines, resulting in adverse peer effects for children from low-income families (Durlauf 1996).

\section{Estimating Intergenerational Mobility}

A major obstacle to systematic empirical research into the link between inequality and intergenerational mobility is the lack of suitable data. The ideal dataset to address this question would have two main features. First, it would be comparable such that crosscountry differences in estimated mobility are meaningful and do not derive from differences in data construction across countries. Second, it would contain panel data on 
the incomes of fathers and sons at economically active ages. The 1999 Social Inequality III module of the International Social Survey Program (ISSP) - which we utilize in this paper - scores highly on the first criteria to the extent that it contains information, collected on a consistent basis, for individuals from a large number of countries. However, this is partly offset by the fact that the ISSP does not explicitly contain data on parental earnings. We therefore follow a spate of previous studies (eg, Bjorklund \& Jantti 1997; Grawe 2001; Leigh 2007), in using predicted parental earnings as a proxy for actual parental earnings.

Our empirical strategy involves a three-step estimation procedure, using data on men aged 25-54 in the 1999 ISSP. First, for each of the 16 countries where data on fathers' occupation is available, we regress the relationship between log hourly wages $y_{i j c}$ of individual $i$ in occupation $j$ on a vector of dummies for each occupation $X_{i j}$, and a quadratic in age $A_{i}$ :

$y_{i j}=\theta_{j}^{\prime} X_{i j}+A_{i}+A_{i}^{2}+\varepsilon_{i j}$

Second, the earnings of fathers in occupation $j$ are then predicted to be the same as those of a 40 year old in occupation $j$. Algebraically, where $\mathrm{A}=40, \hat{y}_{f=j}=\hat{y}_{j}$.

Third, we estimate the relationship between sons' actual log hourly wages and fathers' predicted log hourly wages. 
$y_{s i}=\alpha+\beta \hat{y}_{f=j}+A_{i}+A_{i}^{2}+\varepsilon_{i}$

These three steps are performed separately for each country in the sample.

The coefficient $\beta$ in equation (2) denotes the intergenerational elasticity (IGE), being the percentage change in the son's earnings for doubling of the father's earnings. Another common measure of intergenerational mobility is $\rho$, the intergenerational correlation (IGC) which is based on estimating the same regression, but with the variance in earnings held constant between the two periods. The relationship between the two measures is a function of the ratio of the standard deviation of earnings in the two generations:

$$
\rho=\beta \frac{\sigma_{f}}{\sigma_{s}}
$$

In this paper, we focus primarily on the IGC because the above approach, which imputes fathers' earnings with fathers' occupations, compresses the variance of fathers' earnings, which in turn inflates our estimates of the IGE. However, we also test the robustness of our results to using the IGE. Estimates of the IGE and IGC for each country are listed in Table A1.

Among employed fathers and sons, three factors drive intergenerational mobility: (i) sons working in different occupations from their fathers (inter-occupational mobility); (ii) sons working in the same occupation but with lower or higher earnings than their fathers 
(intra-occupational mobility); and (iii) changes in the average earnings of occupations over time. The method employed here will capture inter-occupational mobility (factor i), but will only capture part of intra-occupational mobility (factor ii), since fathers in the same occupation are assigned the same wage. Moreover, this approach will not take account of changes in the average earnings of occupations over time (factor iii). To gauge the likely importance of this issue, we use microdata from US Censuses to calculate the mean age-adjusted log earnings of men aged 25-54 in 192 occupations. The correlation between an occupation's mean earnings in 1970 and 2000 was 0.71 . While this correlation is reassuringly high, there is still a possibility that our approach will misestimate the true level of intergenerational mobility.

To help validate our estimates, we calculated the correlation between our estimated levels of intergenerational mobility and those published elsewhere. With three common countries, the correlation between our IGCs and those of Jäntti et al (2005) is 0.70. With four common countries, the correlation between our IGEs and those of Solon (2002) is 0.77 .

\section{Inequality and Social Mobility}

To measure income inequality, we use the Gini coefficient: a measure of the income gap between two randomly selected individuals in the population. Where possible, we utilize the Luxembourg Income Study (LIS) -- probably the most reliable source for crosscountry estimates of income inequality (Atkinson 2004). For the four countries in our sample that do not participate in the LIS, we use the highest quality estimate from the 
Deininger and Squire (1996) database. We use the closest estimate to the year 1975 - the likely period when the parents in the sample were making decisions about investments in their children's human capital (the sons in our sample were aged 25-54 in 1999, so they were aged 1-30 in 1975). For Australia, the Czech Republic, Hungary, Poland, Slovakia and Spain, LIS estimates of income inequality are only available for the 1980s and 1990s, though estimates for the early 1970s are available in the Deininger-Squire database. For these countries, a tradeoff exists between using the most appropriate time period and the highest-quality inequality estimates. As such, we also conduct our analysis using data sourced solely from each dataset.

The relationship between inequality and intergenerational mobility for all 16 countries in our sample is depicted in Figure 1. While a positive relationship between inequality and intergenerational mobility is discernible, this is not statistically significant at conventional levels. However, for the six former Warsaw Pact countries in our sample, which were not market economies in the 1970s, it may be unreasonable to draw a link between inequality in the 1970s and intergenerational mobility between the 1970s and late 1990s. (Recall that the theoretical explanations suggesting a relationship between inequality and social mobility include private expenditure on education, political donations, and median voter models. These are more likely to apply in capitalist democracies than in Communist countries.) 


\section{Figure 1: Full Sample}

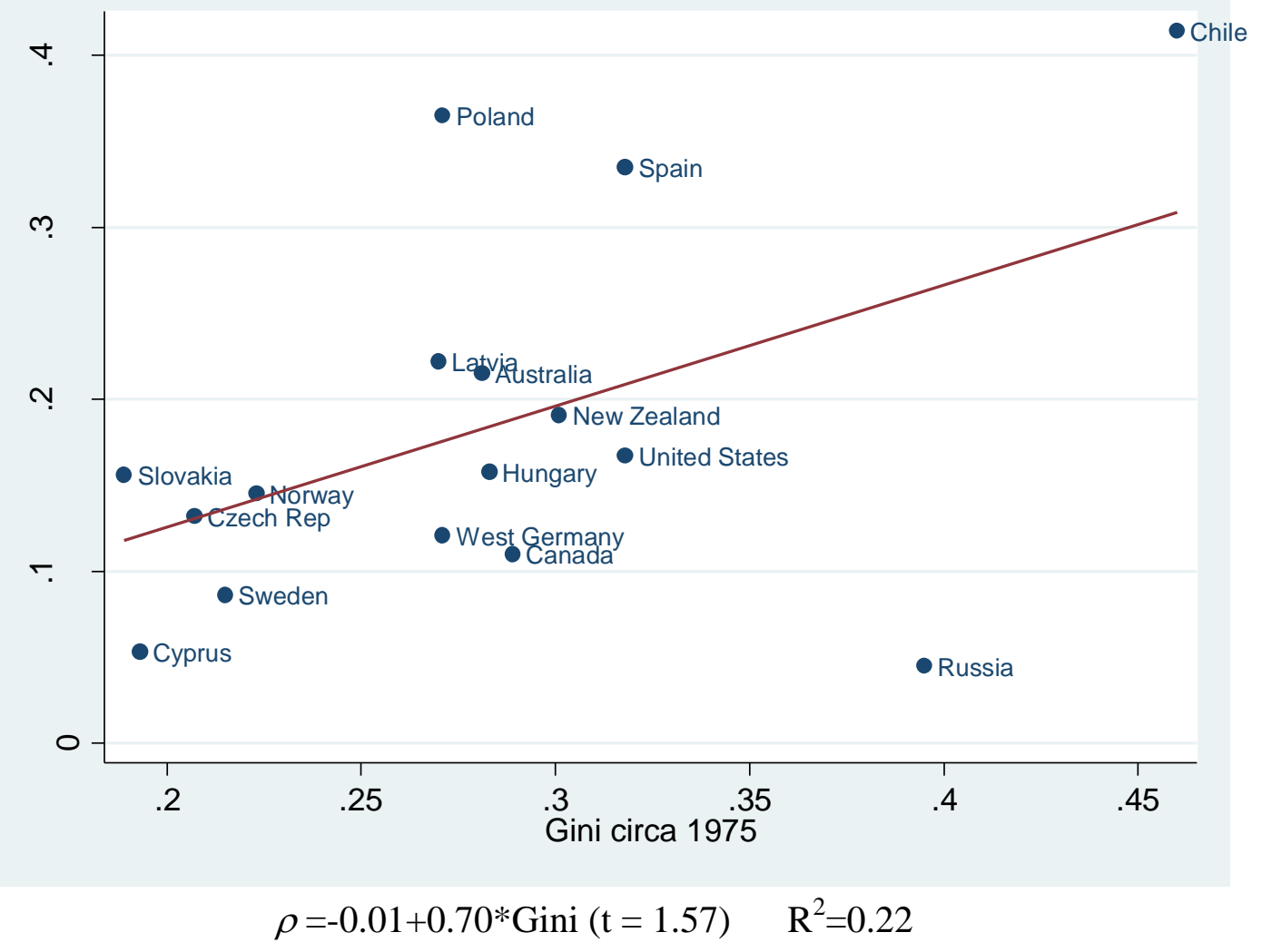

As such, Figure 2 excludes the six former Warsaw Pact countries. The coefficient on inequality becomes statistically significant at the one per cent level and the magnitude of the coefficient almost doubles. In addition, the $\mathrm{R}^{2}$ rises to 0.71 . To account for the possibility that these statistical results are gaining leverage from the inclusion of Chile, we excluded this country from the sample and re-estimated the model. Even when we dropped Chile, however, the Gini coefficient was significant at the 6 per cent level. 


\section{Figure 2: Excluding Former Communist Countries}

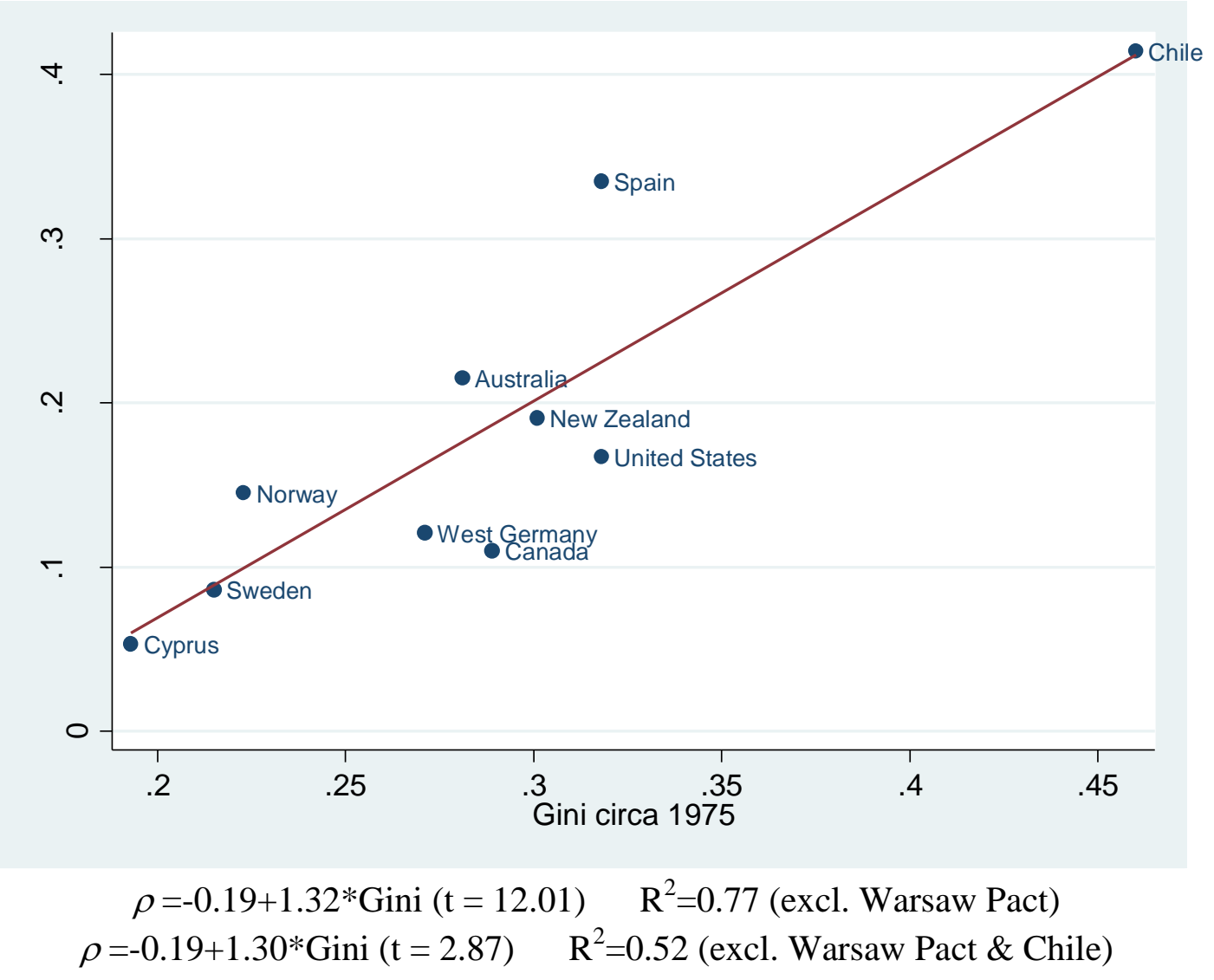

We performed a series of robustness checks to confirm these results. First, we reestimated our results using Gini coefficients sourced exclusively from the DeiningerSquire database, which contains inequality measures of lower quality but of the appropriate vintage (the database has pre-1980 inequality measures for all but two countries, Russia and Latvia). Second, we used only Gini coefficients from the LIS database, whose estimates are generally regarded as higher quality, but are not necessarily derived from surveys in the 1970s. Third, we re-specified the dependent variable to the IGE instead of the IGC. Fourth, we added controls for the rate of return to education in the 1970s, and the log of GDP per capita in 1975 (sources for these variables 
are described in the Data Appendix). In each of these robustness checks, and in combinations of them, the results are very close to those above, both in magnitude and statistical significance. The only exception is that when we use solely LIS inequality estimates, the coefficient on the IGC/IGE is not statistically significant at conventional levels. By contrast, when we use Gini coefficients sourced exclusively from the Deininger-Squire database, the relationship between inequality and the IGC/IGE is statistically significant at the 5\% level, even including the former Warsaw Pact countries.

\section{Conclusion}

Using cross-country data, we find that sons who grew up in more unequal countries in the 1970s were less likely to have experienced social mobility by 1999. Across countries, our estimates suggest that a 10-point rise in the Gini coefficient is associated with a $0.07-0.13$ increase in the intergenerational earnings correlation. Moving from rags to riches is harder in more unequal countries. 


\section{References}

Alesina, A \& EL Glaeser (2004), Fighting Poverty in the US and Europe: A World of Difference. (Oxford: University Press).

Atkinson, AB (2004), "The Luxembourg Income Study (LIS): Past, Present and Future" Socio-Economic Review Vol. 2: 165-190.

Björklund, A \& M Jäntti (1997). "Intergenerational Income Mobility in Sweden Compared to the United States." American Economic Review. Vol. 87, 1009-18.

Burtless, G \& C Jencks (2003), "American Inequality and its Consequences" in H Aaron, JM Lindsay \& PS Nivola (eds.), Agenda for the Nation (Washington DC: Brookings) pp 61-108.

Durlauf, S (1996), "A Theory of Persistent Income Inequality" Journal of Economic Growth (1):75-93.

Deininger, K \& N Squire (1996), “A New Data Set Measuring Income Inequality” World Bank Economic Review 10(3): 565-91.

Grawe, N., (2001). 'Intergenerational Mobility in the US and Abroad: Quantile and Mean Regression Measures'. Ph.D. Dissertation, Department of Economics, University of Chicago.

Jantti, M, B Bratsberg, K Røed, O Raaum, R Naylor, E Österbacka, A Björklund \& T Eriksson (2006), "American exceptionalism in a new light: a comparison of intergenerational earnings mobility in the Nordic countries, the United Kingdom and the United States" IZA Discussion Paper No. 1938.

Jencks, C \& L Tach (2006), "Would Equal Opportunity Mean More Mobility? In S Morgan, D Grusky, and G Fields (eds), Mobility and Inequality: Frontiers of Research from Sociology and Economics, Stanford University Press, Palo Alto, CA, 23-58.

Leigh, A (2007), "Intergenerational Mobility in Australia" Unpublished mimeo, Australian National University.

Maddison, A. (2003), The World Economy: Historical Statistics, OECD Development Centre, Paris.

Psacharopoulos, G (1981), "Returns to Education: an Updated International Comparison" Comparative Education 17(3): 321-41.

Solon, G. (2002), "Cross-Country Differences in Intergenerational Earnings Mobility" Journal of Economic Perspectives 16(3): 59-66.

Solon, G (2004), “A Model of Intergenerational Mobility Variation over Time and Place." in M Corak (editor). Generational Income Mobility in North America and Europe (Cambridge: Cambridge University Press): 38-47. 


\section{Data Appendix}

Intergenerational correlations and elasticities: Estimated using data on men aged 2554 from the 1999 Social Inequality III module from the International Social Survey Programme (ISSP). The survey covers both West Germany and East Germany (since four-fifths of the population of Germany lives in what was formerly West Germany, our estimate of the level of intergenerational mobility in Germany should be close to the true level in West Germany). See text for details on how the IGCs and IGEs are derived. Hourly wages are estimated as annual earnings divided by (weekly hours multiplied by 52). The earnings question was asked consistently within each country, but the treatment of deductions and taxation varied. Occupations in the ISSP are coded based on the four digit 1988 ISCO/ILO occupation coding scheme.

Gini coefficients: Graphs and regressions shown in the paper are based upon LIS Gini coefficients where available, and Deininger-Squire Gini coefficients otherwise. We use the gini coefficient in preference to other measures of inequality since it is more readily available for earlier years. Although the LIS dataset contains measures such as the 90/10 and the Atkinson index, these inequality measures are not available in the DeiningerSquire database.

LIS Gini coefficients: Sourced from the Luxembourg Income Study Key Figures, accessed at http://www.lisproject.org/keyfigures/ineqtable.htm on January 11, 2007. We used the year closest to 1975 .

Deininger-Squire Gini coefficients: Sourced from the World Income Inequality Database, version 2.0a (June 2005), available at http://econ.worldbank.org. We only choose estimates that were labeled as quality="accept" in the Deininger-Squire database. However, the Gini coefficient for Cyprus is based on a survey of less than national coverage (quality="nn"). For the Czech Republic and Slovakia, we use the Gini coefficient for Czechoslovakia. For Russia, we use the Gini coefficient for the USSR. For all countries, the gini was calculated as close as possible to 1975 .

Rate of return to education: Sourced from Table 1 in Psacharopoulos (1981). We use the estimate closest to 1975. Estimates show the private rate of return to attaining higher education, relative to secondary education. We use this estimate on the basis that it is available for the maximum number of countries in our sample. Other rates of return, such as the increase in log earnings associated with an additional year of schooling, are only available for a smaller number of countries in Psacharopoulos's survey. Although attaining higher education was relatively uncommon in the 1970s for young people in most countries, we regard the returns to higher education as a proxy for the returns across all types of education. Across countries, Psacharopoulos's results show a high correlation between the returns to education at different levels. No adjustment is made for ability bias.

Average GDP per capita in 1975: Measured in 1990 US dollars per capita, sourced from Maddison (2003). For the Czech Republic and Slovakia, we use the GDP for 
Czechoslovakia. For Russia and Latvia, we use the GDP for the USSR. For Cyprus, we use the GDP for Greece. 


\section{Table A1: Descriptive Statistics}

Parentheses contain standard errors for mobility estimates or year of estimate otherwise

\begin{tabular}{|c|c|c|c|c|c|c|}
\hline & \multicolumn{2}{|c|}{$\begin{array}{c}\text { Intergenerational } \\
\text { Income Mobility in } \\
1999\end{array}$} & \multicolumn{2}{|c|}{ Gini circa 1975} & \multirow{2}{*}{$\begin{array}{c}\text { Rate of } \\
\text { Return to } \\
\text { Education } \\
\text { circa } 1975 \\
\text { Per cent }\end{array}$} & \multirow{2}{*}{$\begin{array}{c}\text { GDP per } \\
\text { Capita in } 1975 \\
\\
\text { US\$ (PPP } \\
\text { method) }\end{array}$} \\
\hline & Correlation & Elasticity & LIS & $\begin{array}{l}\text { Deininger- } \\
\text { Squire }\end{array}$ & & \\
\hline Australia & $\begin{array}{c}0.215 \\
(0.066)\end{array}$ & $\begin{array}{c}0.326 \\
(0.100)\end{array}$ & $\begin{array}{c}0.281 \\
(1981)\end{array}$ & $\begin{array}{c}0.343 \\
(1976)\end{array}$ & $\begin{array}{c}13.9 \\
(1969)\end{array}$ & 13170 \\
\hline Canada & $\begin{array}{c}0.110 \\
(0.067)\end{array}$ & $\begin{array}{c}0.152 \\
(0.094)\end{array}$ & $\begin{array}{c}0.289 \\
(1975)\end{array}$ & $\begin{array}{l}0.316 \\
(1975)\end{array}$ & $\begin{array}{c}19.7 \\
(1961)\end{array}$ & 14316 \\
\hline Chile & $\begin{array}{c}0.414 \\
(0.071)\end{array}$ & $\begin{array}{c}0.571 \\
(0.098)\end{array}$ & -- & $\begin{array}{c}0.46 \\
(1971)\end{array}$ & -- & 4323 \\
\hline Cyprus & $\begin{array}{c}0.053 \\
(0.066)\end{array}$ & $\begin{array}{c}0.087 \\
(0.109)\end{array}$ & -- & $\begin{array}{c}0.256 \\
(1966)\end{array}$ & $\begin{array}{c}14.8 \\
(1975)\end{array}$ & 7722 \\
\hline Czech Republic & $\begin{array}{c}0.132 \\
(0.057)\end{array}$ & $\begin{array}{c}0.204 \\
(0.088)\end{array}$ & $\begin{array}{c}0.207 \\
(1992)\end{array}$ & $\begin{array}{l}0.207 \\
(1976)\end{array}$ & -- & 7399 \\
\hline $\begin{array}{l}\text { Germany } \\
\text { (West) }\end{array}$ & $\begin{array}{c}0.121 \\
(0.095)\end{array}$ & $\begin{array}{c}0.165 \\
(0.130)\end{array}$ & $\begin{array}{c}0.271 \\
(1973)\end{array}$ & $\begin{array}{c}0.306 \\
(1973)\end{array}$ & $\begin{array}{c}4.6 \\
(1964)\end{array}$ & 12041 \\
\hline Hungary & $\begin{array}{c}0.158 \\
(0.101)\end{array}$ & $\begin{array}{c}0.222 \\
(0.142)\end{array}$ & $\begin{array}{c}0.283 \\
(1991)\end{array}$ & $\begin{array}{l}0.215 \\
(1977)\end{array}$ & -- & 5805 \\
\hline Latvia & $\begin{array}{c}0.222 \\
(0.079)\end{array}$ & $\begin{array}{c}0.278 \\
(0.099)\end{array}$ & -- & $\begin{array}{c}0.270 \\
(1993)\end{array}$ & -- & 6135 \\
\hline New Zealand & $\begin{array}{c}0.191 \\
(0.083)\end{array}$ & $\begin{array}{c}0.245 \\
(0.107)\end{array}$ & -- & $\begin{array}{l}0.300 \\
(1975)\end{array}$ & $\begin{array}{c}14.7 \\
(1966)\end{array}$ & 12489 \\
\hline Norway & $\begin{array}{c}0.145 \\
(0.048)\end{array}$ & $\begin{array}{c}0.236 \\
(0.089)\end{array}$ & $\begin{array}{c}0.223 \\
(1979)\end{array}$ & $\begin{array}{c}0.373 \\
(1976)\end{array}$ & $\begin{array}{c}7.7 \\
(1966)\end{array}$ & 12180 \\
\hline Poland & $\begin{array}{c}0.365 \\
(0.084)\end{array}$ & $\begin{array}{c}0.396 \\
(0.092)\end{array}$ & $\begin{array}{c}0.271 \\
(1986)\end{array}$ & $\begin{array}{c}0.258 \\
(1976)\end{array}$ & -- & 5808 \\
\hline Russia & $\begin{array}{c}0.045 \\
(0.069)\end{array}$ & $\begin{array}{c}0.060 \\
(0.093)\end{array}$ & $\begin{array}{c}0.395 \\
(1992)\end{array}$ & $\begin{array}{c}0.246 \\
(1980)\end{array}$ & -- & 6135 \\
\hline Slovakia & $\begin{array}{c}0.156 \\
(0.073)\end{array}$ & $\begin{array}{c}0.247 \\
(0.115)\end{array}$ & $\begin{array}{c}0.189 \\
(1992)\end{array}$ & $\begin{array}{c}0.207 \\
(1976)\end{array}$ & -- & 7399 \\
\hline Spain & $\begin{array}{c}0.335 \\
(0.101)\end{array}$ & $\begin{array}{c}0.402 \\
(0.121)\end{array}$ & $\begin{array}{c}0.318 \\
(1980)\end{array}$ & $\begin{array}{c}0.371 \\
(1973)\end{array}$ & $\begin{array}{c}15.5 \\
(1971)\end{array}$ & 8346 \\
\hline Sweden & $\begin{array}{c}0.086 \\
(0.077)\end{array}$ & $\begin{array}{c}0.104 \\
(0.092)\end{array}$ & $\begin{array}{c}0.215 \\
(1975)\end{array}$ & $\begin{array}{c}0.273 \\
(1975)\end{array}$ & $\begin{array}{c}10.3 \\
(1967)\end{array}$ & 14183 \\
\hline United States & $\begin{array}{c}0.167 \\
(0.093)\end{array}$ & $\begin{array}{c}0.238 \\
(0.131)\end{array}$ & $\begin{array}{c}0.318 \\
(1974)\end{array}$ & $\begin{array}{c}0.344 \\
(1975)\end{array}$ & $\begin{array}{c}15.4 \\
(1969)\end{array}$ & 16284 \\
\hline $\begin{array}{l}\text { Unweighted } \\
\text { Mean }\end{array}$ & $\begin{array}{c}0.182 \\
(0.077)\end{array}$ & $\begin{array}{c}0.246 \\
(0.105)\end{array}$ & 0.272 & 0.297 & 12.2 & 9608 \\
\hline
\end{tabular}

